\title{
The Study of Doxorubicin and its Complex with DNA by SERS and UV-resonance Raman Spectroscopy
}

\author{
Chul Jae Lee, Jae Soo Kang, Mak Soon Kim, Kwang Pill Lee, and Mu Sang Lee \\ Department of Chemistry Education, Kymgpook National Lniversity, Daegu 702-701. Korea \\ Received March 30, 2004
}

\begin{abstract}
The interaction of the antitumour agent doxorubicin with calf thymus DNA is investigated in an aqueous solution at a pH level of 6-7 with molar ratios of 1/10. A UV-resonance Raman spectroscopy and surface enhanced Raman spectroscopy are used to determine the doxorubicin binding sites and the structural variations of doxorubicin-DNA complexes in an aqueous solution. Doxorubicin intercalates with adenine and guanine via a hydrogen bond formation between the $\mathrm{N} 7$ positions of purine bases and the hydroxyl group of doxorubicin.
\end{abstract}

Key Words : [JV-resonance Raman spectroscopy, SERS, DNA, Doxorubicin

\section{Introduction}

Many DNA intercalators have been shown to have antitumour and antibiotic activity. ${ }^{1-3}$ This biological property has been attributed to the formation of the intercalation complexes between the chromophore and the base pairs of DNA. ${ }^{4.5}$ The changes in the overall structure of the drugDNA complexes provide a possible explanation for the differences in the clinical activity of the drugs ${ }^{6.7}$ There are a few techniques available regarding molecular interaction within complicated supramolecular complexes. Raman spectroscopy has excellent fingerprinting capability. In particular, UV-resonance Raman spectroscopy has been widely used because of its selectivity which permits the observation of bands corresponding only to the vibration of the chromophore and sensitivity in monitoring the structure of nucleobases and nucleosides. ${ }^{8-10}$ Surface enhanced Raman scattering (SERS) has been used as a powerful method which can obtain information from fluorescent chromophores. $^{11-15}$ In general, the observation of the SERS effect requires the presence of nanometer-scaled roughness $(10-500 \mathrm{~nm})$ on the metal surface. The analytical applications employed metal-coated microspheres. ${ }^{16}$ silver thin film (by silver mirror reaction), LB (Langmuir-Blodgett) film, ${ }^{17}$ and metal colloids ${ }^{18.19}$ as the SERS-active substrates. Since the silver thin film was reported to be easily obtained and it has superior surface enhancement on the Raman signal, ${ }^{2 t)}$ we used it for our present study. Figure 1 shows the chemical structure of doxorubicin. Doxorubicin is a cytotoxic drug which is widely used in the treatment of many malignant diseases due to its broad antitumour activity. ${ }^{21,22}$ The biological activity of doxorubicin seems to be due to its complexation with DNA.

Beljebbar et al: reported on the characterization of doxorubicin and its complex with DNA using the fourier transform surface enhanced Raman scattering (F[-SERS) and surface enhanced resonance Raman scattering (SERRS). According to this paper, studies have been focused on the fact that doxorubicin-DNA complex can be observed by Near Infrared (NIR) (1064 nm) and Visible (514 nm) laser excitation sources. In the case of doxorubicin in free form, it is possible to be observed by this excitation source but it is impossible to be observed by free DNA., ${ }^{3 . ? 3}$ lhere haven't been any studies that tried to UV-resonance Raman scattering (UV-RRS). It is essential to find out the interaction site of doxorubicin-DNA complex. In order to explain further about the effect of DNA when it makes doxorubicinDNA complex, it is necessary to use UV-RRS. Because the $\pi \rightarrow \pi^{\prime}$ transition of nucleic acid bases for DNA is $260 \mathrm{nIn}$. Therefore in this paper, first, we will show the measurements of doxorubicin-DNA complex by UV-RRS. Second, we

(a)

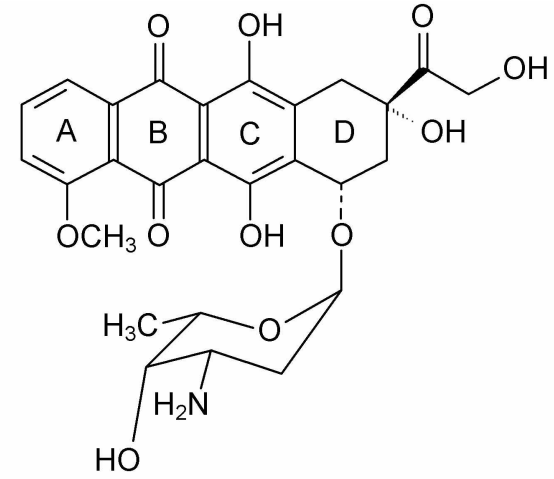

(b)

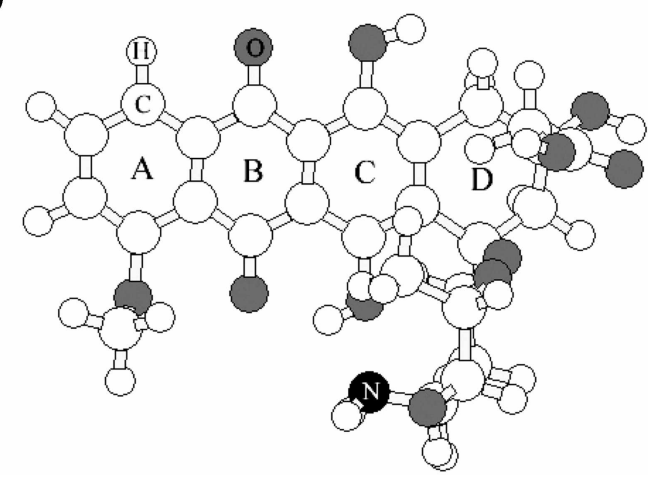

Figure 1. Chemical structure of doxorubicin: (a) two dimensional strueture (b) three dimensional structure. (calculated from HyperChem 7.0 program) 


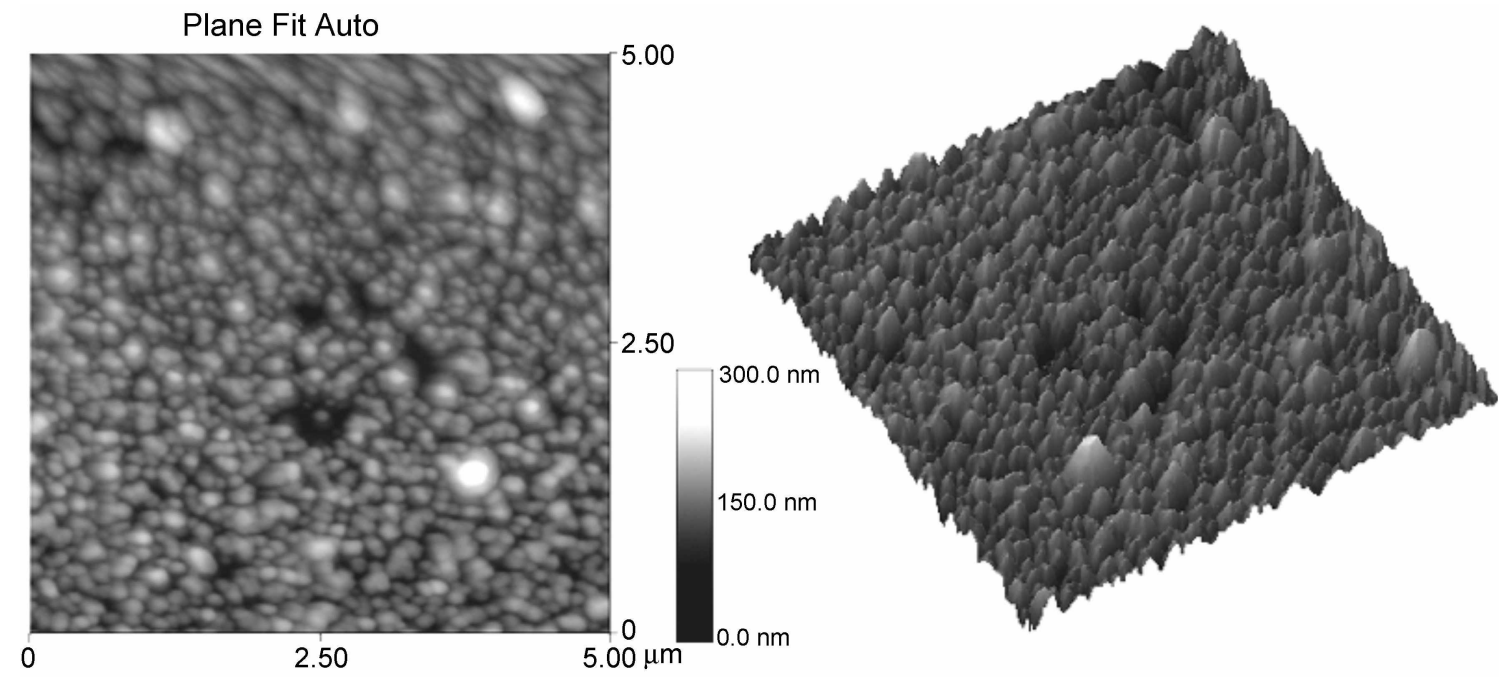

Figure 2. $\mathrm{Al} \mathrm{M}$ images of silver mirror substrates.

measure doxorubicin-DNA complex by STRS. As a result, we will report on the interaction site of DNA and doxorubicin for doxorubicin-DNA complex.

\section{Experimental Section}

Instrumentation. The SERS spectrum was obtained using a Jobin-Yvon Horiva HR800 scaming single monochromator, a CCD 3000(V) detector and labspec 4.01 software. A Coherent Innova $90 \mathrm{C}$ Fred ${ }^{\mathrm{TN}}$ argon ion laser ( $\lambda$ $=514.5 \mathrm{~nm})$ was used as the excitation source. The laser power and confocal hole size were $5 \mathrm{~mW}$ and $400 \mu \mathrm{m}$, respectively. The UV-RRS spectra of doxorubicin, and DNA-doxorubicin complex were obtained in the 200-1800 $\mathrm{cm}^{-1}$ range using the $257 \mathrm{~nm}$ excitation. That line was derived from Second Harmonic Generation (SHG) optics. The laser power and confocal hole size were $1 \mathrm{~mW}$ and 600 $\mu \mathrm{m}$, respectively. The UV-visible absorption spectra were measured using a Shimadzu UV-360 P'C instrument. Atomic Force Microscope (AFM) image was obtained using a Digital Instrument Nanoscope Illa.

Chemicals. Doxorubicin (Aldrich), calf thymus DNA (Sigına), silver nitrate (JUNSEI), D-glucose (Aldrich), sodium hydroxide (JUNSEl), and ammonium hydroxide (JUNSEI) were analytical reagents or the equivalent and were used without further purification. Iriply distilled water was used in preparing the sample solutions and silver mirror substrates.

Procedure. Silver mirror substrate was prepared by the Jollen's test, which is widely used for the identification of aldehyde. ${ }^{24}$ A glass plate of $25 \mathrm{~mm} \times 10 \mathrm{~mm} \times 1 \mathrm{~mm}$ was put in a culture dish. A $10 \mathrm{~mL}$ of $5 \%$-silver ammonia solution and $5 \mathrm{~mL}$ of $10 \%$-sodium hydroxide solution were mixed in the culture dish. Then. $10 \mathrm{~mL}$ of $5 \%$-D-glucose was added to the mixing solution. A few minutes later, the color of the solution turned to yellow, then dark brown. In the meanwhile, silver ions were reduced and deposited onto the glass plate to form a fine silver film called a silver mirror.
After withdrawing the silver mirror from a culture dish, it was washed with distilled water. AFM was used for measuring the silver particle sizes on the silver mirrors. The silver particle sizes on the silver mirror are $150-300 \mathrm{~nm}$. Figure 2 shows AFM images of silver mirror substrates.

DNA sample wats prepared by dissolving small amounts of calf thymus DNA in water at $5{ }^{\circ} \mathrm{C}$ for 24 hour with occasional stirring to ensure the formation of a homogeneous solution. Next, the solution was put in a centrifugal separator for $2000 \mathrm{rpm}$. The resulting viscous solution was clear and particle-free. The concentration of calf thymus DNA solution was calculated by the sample absorbance at $257 \mathrm{~nm}\left(\varepsilon_{257}=13.2 \mathrm{~cm}^{-1} \mathrm{mM}^{-1} /\right.$ base pair $) .^{25}$ Doxorubicin stark solution of $10^{-3} \mathrm{M}$ was prepared in triply distilled water and diluted to the desired concentration before each experiment. The mixed solution was prepared by adding doxorubicin acjueous solution in a concentration of $10^{-1} \mathrm{M}$ to DNA solution with constant stirring. The final molar ratio of doxorubicin/DNA was $1 / 10$.

\section{Results and Discussion}

UV-visible absorption spectra of the calf thymus DNA. doxorubicin and doxorubicin-DNA complex were presented in Figure 3 . The inset of the figure exhibits the Raman spectra of doxorubicin and blank condition probed at 257 nm. From this Raman spectrum, it can be seen that doxorubicin does not exhibit a resonance enhancement for this excitation line. This phenomenon gives us an advantage for doxorubicin-DNA complex study. As for $257 \mathrm{~nm}$ excitation. only the DNA base vibration modes are enhanced. Therefore, the doxorubicin vibrational modes do not participate in the UV-resonance Raman spectrum of the doxorubicin-DNA complex.

Figure 4 shows the UV-RRS spectra of calf thymus DNA [Figure (4a)] and doxorubicin-DNA complex [Figure (4b)]. The excitation in the absorption maximum of DNA molecule leads to the resonance enhancement of DNA bases, adenine 


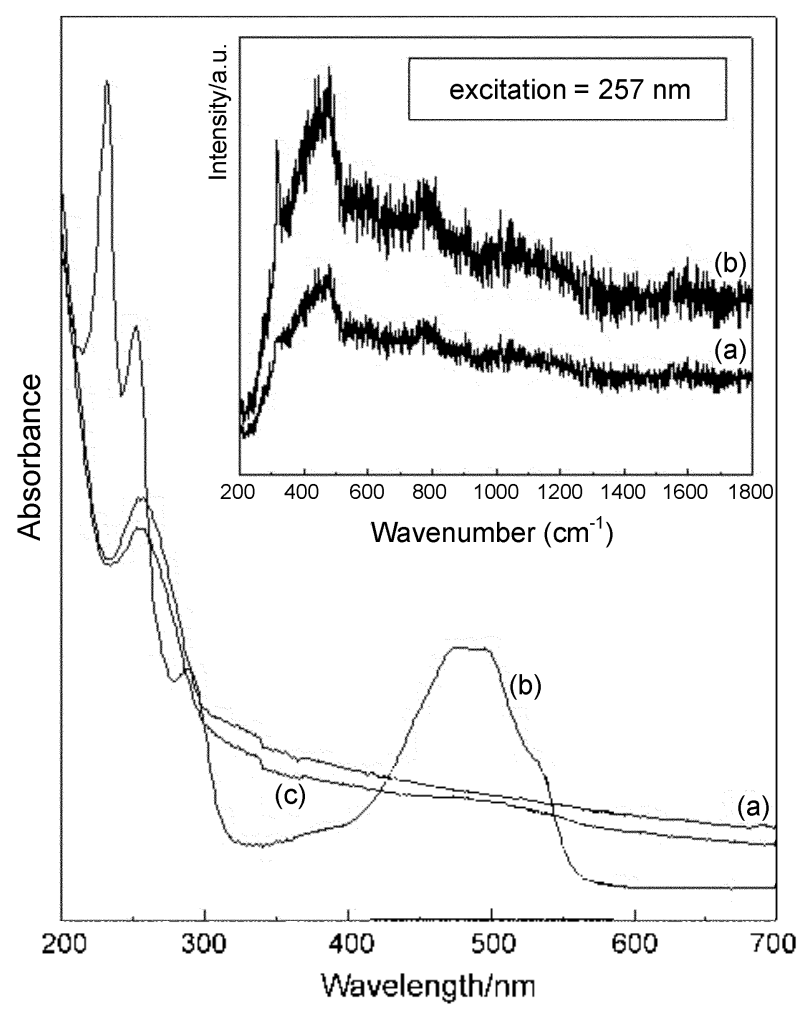

Figure 3, IV-risible absorption spectra of (a) $1.1 \times 10^{-5} \mathrm{M}$ ol call thymus DNA. (b) $1.0 \times 10^{+} \mathrm{M}$ of doxorubicin and (c) $1.0 \times 10^{6} \mathrm{M}$ of doxorubicin. $1.0 \times 10^{-5} \mathrm{M}$ of DNA complex. Inset figure: Raman spectra of (a) $1.0 \times 10^{-1} \mathrm{M}$ of doxorubicin and (b) blank. I aser power $=1 \mathrm{~mW}$.

and guanine in particular. Due to this resonance enhancement for the DNA vibrational modes, all observed spectral changes in the complexation of doxorubicin with the calf thymus DNA can be associated with the structural changes of calf thymus DNA molecule, which is caused by the interaction with doxorubicin. The observed Raman frequencies and their assignments of calf thymus DNA and doxorubicinDNA complex are listed in lable 1. ${ }^{320.27}$ Four intense bands at $1346,1385,1480$ and $1621 \mathrm{~cm}^{-1}$ can be seen in calf thymus DNA UV-RRS spectrum [rigure (4a)]. Fodor $e t a l^{8}$ have measured the UV-RRS spectra of deoxyribonucleotides using the excitation at 266240,218 and $200 \mathrm{~nm}$. The UVRRS spectrum of deoxyadenosine 5'-phosphoric acid (dAMP) obtained with the $266 \mathrm{~nm}$ excitation shows characteristic bands at 1339 and $1604 \mathrm{~cm}^{-1}$. Likewise, the UV-resonance Raman spectrum of deoxyguanosine 5'-phosphoric acid (dGMP) contains bands at 1489 and $1578 \mathrm{~cm}^{-1}$. Thus, in our calf thymus DNA UV-RRS spectrum [Figure (4a)], we can easily assign the band at $1346 \mathrm{~cm}^{-1}$ to adenine vibrations and the band at $1480 \mathrm{~cm}^{-1}$ to guanine vibrations. Finally, the band at $1385 \mathrm{~cm}^{-1}$ can be attributed to thymine vibrations and the band at $1621 \mathrm{~cm}^{-1}$ to adenine vibrations. These bands were also observed in the study of deoxythymidine 5'phosphoric acid (d'IMP) and deoxyadenosine 5'-phosphoric acid (dAMP) excitated at $266 \mathrm{~nm}$ by fordor et al. ${ }^{8}$.

The formation of doxorubicin-DNA complex can be observed in the spectrum. The bands at 1346 and $1621 \mathrm{~cm}^{-1}$

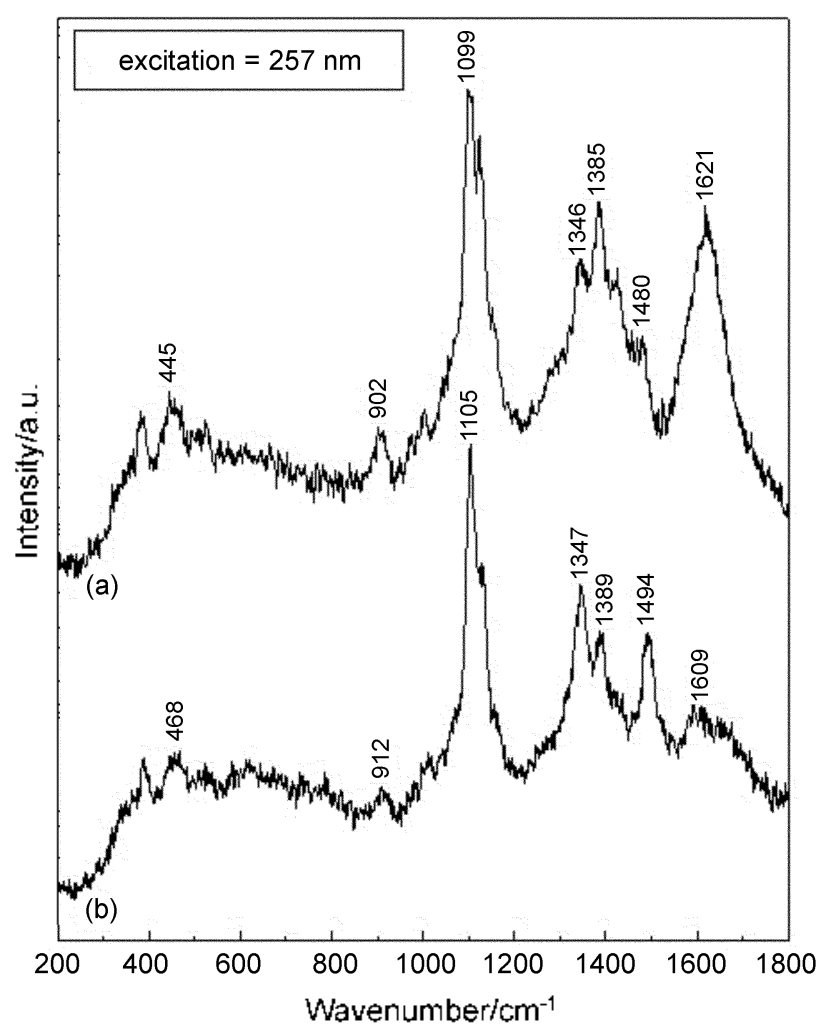

Figure 4. LV-resonance Raman spectra of (a) $1.1 \times 10^{5} \mathrm{M}$ of calf thymus DAA. (b) $1.0 \times 10^{-6} \mathrm{M}$ of doxorubicin - $1.0 \times 10^{-5} \mathrm{M}$ of D. A complex. (molar ratio $1: 10$ )

for adenine and $1480 \mathrm{~cm}^{-1}$ for guanine bands are enlanced and shifted in the complex spectrum in comparison to DNA isolated molecule. As a consequence of this change. the bands at 1347, $1609 \mathrm{~cm}^{-1}$ (for adenine) and $1494 \mathrm{~cm}^{-1}$ (for guanine) are observed in the spectrum [Figure (4b)]. From the previous analysis, we can conclude that the doxorubicin interacts preferentially with adenine and guanine molecules. The bands at 1346 and $1621 \mathrm{~cm}^{-1}$ are mainly caused by the $\mathrm{N} 7 \mathrm{C} 5+\mathrm{C} 8 \mathrm{~N} 7$ and $\delta \mathrm{NH}_{2}-\mathrm{C} 5 \mathrm{C} 6+\mathrm{C} 6 \mathrm{~N} 6$ adenine group vibrations, respectively. 8.27 Thus, the intensity increase of band at $1347 \mathrm{~cm}^{-1}$ and the red-shift from 1621 to $1609 \mathrm{~cm}^{-1}$ of adenine are caused mainly by the doxorubicin interaction with the $\mathrm{N} 7$ position of adenine, which is accessible for doxorubicin in the major groove of DNA structure.

Table 1. Resonance Raman frequencies $\left(\mathrm{cm}^{-1}\right)$ and assignnents of calf thymus DNA and doxorubicin-DNA complex observed with excitation at $257 \mathrm{~nm}$

\begin{tabular}{cclc}
\hline $\begin{array}{c}\text { call thymus } \\
\text { 1)NA }\end{array}$ & $\begin{array}{c}\text { dexorubiciu- } \\
\text { I)NA }\end{array}$ & \multicolumn{1}{c}{ Assignment } & Ref. \\
\hline $1099 \mathrm{~s}$ & $1105 \mathrm{~s}$ & $\mathrm{PO}_{2}^{-}$ssmmetric stretch & 23 \\
$1346 \mathrm{w}$ & $1347 \mathrm{~m}$ & $\mathrm{~A}(-\mathrm{N} 7 \mathrm{C} 5+\mathrm{C} 8 \mathrm{~N} 7)$ & 8.24 \\
$1385 \mathrm{~m}$ & $1389 \mathrm{w}$ & $\mathrm{T}(\mathrm{C} 6 \mathrm{C} 5-\mathrm{C} 40)$ & 8.24 \\
$1480 \mathrm{w}$ & $1494 \mathrm{~m}$ & $\mathrm{C}(\delta \mathrm{C} 8 \mathrm{H}-\mathrm{N} 9 \mathrm{C} 8-\mathrm{C} 8 \mathrm{~N} 7)$ & 8.24 \\
$1621 \mathrm{~s}$ & $1609 \mathrm{w}$ & $\mathrm{A}(\delta \mathrm{NH} 2-\mathrm{C} 5 \mathrm{C} 6+(6 \mathrm{~N} 6)$ & 8 \\
\hline
\end{tabular}

(abbrevialions: s. strong: m, medium: w, weak: $A$, adenine: $(j$, guanine: T. thytuine: (. cytosine: $\delta$. in plane bending ) 
The localization of doxorubicin molecule in the major groove of DNA can influence the $-\mathrm{NH}_{2}$ vibration of adenine molecule. This is the reason why the complex formation leads to the appearance of the $1609 \mathrm{~cm}^{-1}$ band [Figure (4b)]. Also, the band at $1385 \mathrm{~cm}^{-1}$ is attributed to the $\mathrm{C} 6 \mathrm{C} 5-\mathrm{C} 4 \mathrm{O}$ thymine group vibrations. The intensity decrease and the b) ue-shift of the thymine band from 1385 to $1389 \mathrm{~cm}^{-1}$ are caused by the deformation of the hydrogen bond between the $\mathrm{NH}_{2}$ group of adenine and the $\mathrm{C} 4 \mathrm{O}$ group of thymine molecule. In the case of guanine, the band at $1480 \mathrm{~cm}^{-1}$ is caused by the $\mathrm{C} 8 \mathrm{H}-\mathrm{N} 9 \mathrm{C} 8$ and $\mathrm{C} 8 \mathrm{~N} 7$ guanine group vibrations [Figure (4a)]. ${ }^{8.23}$ We think that the intensity increase and blue-shift of the guanine band from 1480 to $1494 \mathrm{~cm}^{-1}$ is caused by the doxorubicin interaction with the $\mathrm{N} 7$ position of guanine.

Thus, from the UV-resonance Raman data, it is clear that doxorubicin interacts with the N7 positions of adenine and guanine and this interaction leads a partial deformation of the hydrogen bonds between adenine and thymine bases. As the $N 7$ positions of guanine and adenine are the protonacceptor sites of adenine and guanine rings, it seems probable that doxorubicin interacts with adenine and guanine via a hydrogen bond formation between the portion of its hydroxyl group and the $\mathrm{N} 7$ position of purines. ${ }^{8.28 .2^{2}}$ The interaction site of doxorubicin and purine rings of DNA are shown in Figure 5.

In order to determine the interaction site of doxorubicin for doxorubicin-DNA complex, we measured the SERS spectra. Figure 6 shows the SERS spectra of $1.0 \times 10^{-6} \mathrm{M}$ of doxorubicin, $1.1 \times 10^{-5} \mathrm{M}$ of calf thymus DNA and $1.0 \times 10^{-6}$ $M$ of doxorubicin $-1.0 \times 10^{-5} \mathrm{M}$ of DNA complex (molar ratio $=1: 10)$. The comparison of the spectrum of free doxorubicin with the doxorubicin-DNA complex reveals a modification in the vibrational frequencies and intensities of several bands [Figure $(6 \mathrm{c})$ ]. The bands at 1275.1410 and $1516 \mathrm{~cm}^{-1}$ corresponded to the $(v \mathrm{C}-\mathrm{O})$ vibration of ring $\mathrm{A}$, the ring stretching vibration and the $(v C=C)$ vibration of ring $A$, respectively. The peak assigments of doxorubicin are given in lable $2 .^{30.31}$ The determination of orientation was based on the SERS "surface selection rule", which stated the vibrations that derived their intensities from a large value of $\alpha_{L u}$ ( $\mathrm{z}$ being the local surface normal) would become the most intense in the SERS spectrum. ${ }^{32.3}$ In the case of doxorubicin, it was taken into account that $\mathrm{C}=\mathrm{O}$ and hydroxyl groups of doxorubicin actively interacted with the

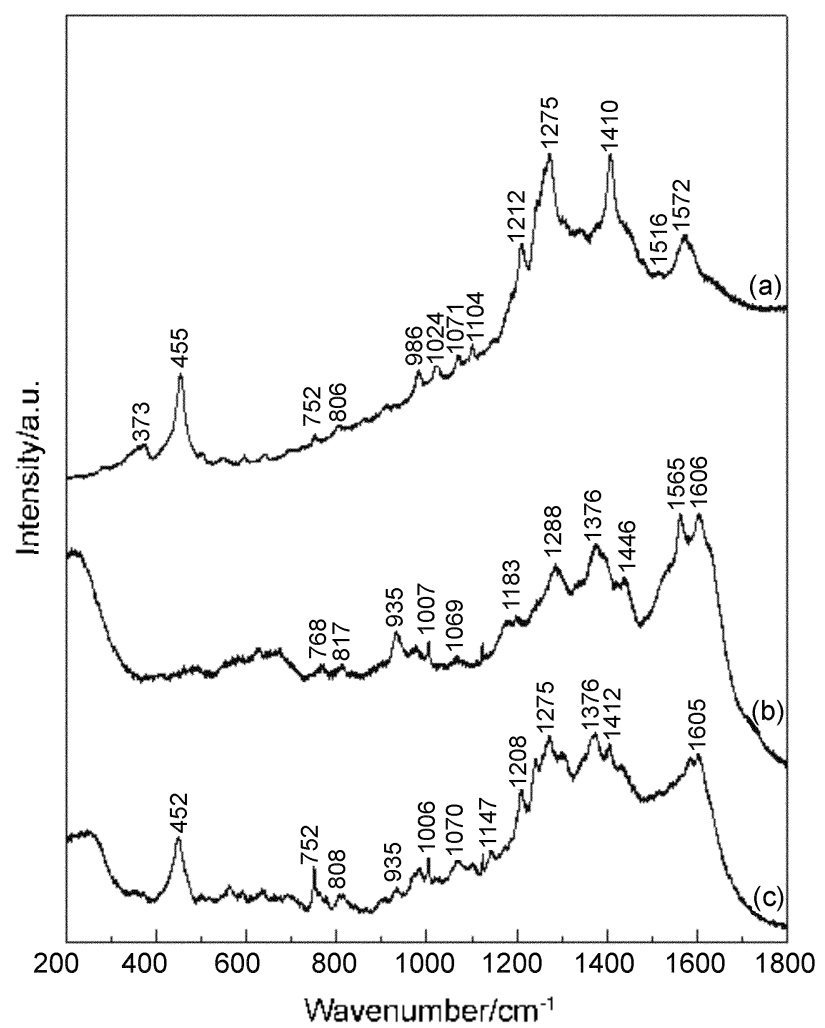

Figure 6. SLRS spectra of (a) $1.0 \times 10^{-6} \mathrm{M}$ of doxorubicin. (b) I.I $\times 10^{-5} \mathrm{M}$ of calf thymus D.A and (c) $1.0 \times 10^{-6} \mathrm{M}$ of doxoruhicin $1.0 \times 10^{-5} \mathrm{M}$ ol D.NA complex. (molar ratio $1: 10$ )

silver mirror surface. Therefore, in-plane vibrational mode for doxorubicin of ring $\mathrm{A}$ is more intense. It seemed that the adsorbed doxorubicin on silver mirror surface may be more inclined to a perpendicular orientation rather than to a flat one. The biological activity of doxorubicin has been attributed to the formation of a complex between the chromophore and base pairs of DNA. ${ }^{30.314}$ The comparison between the SERS spectrum of free doxorubicin and doxorubicin-DNA complex showed the loss of intensity together with the disappearance of some bands upon complexation. From this viewpoint, we suggested that the interaction sites of doxorubicin were $\mathrm{C}=\mathrm{O}$ and hydroxyl group. In Figure 7, the SERS spectra of $1.0 \times 10^{-6} \mathrm{M}$ of doxorubicin. $1.1 \times 10^{-5} \mathrm{M}$ of calf thymus DNA and $1.0 \times 10^{-6}$ $\mathrm{M}$ of doxorubicin $-1.0 \times 10^{-5} \mathrm{M}$ of DNA complex (molar ratio $=1: 10$ ) are shown in $3000 \mathrm{~cm}^{-1}$ region. In the case of

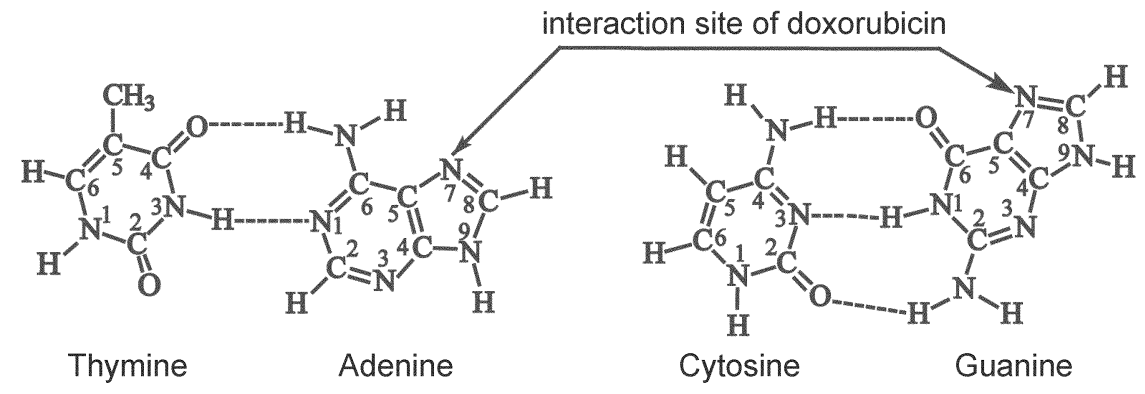

Figure 5. The diagram of the interaction site of doxorubicin and purine rings of $D . N A$. 
Table 2. Vibrational frequencies $\left(\mathrm{cm}^{-1}\right)$ of major bands in SERS spectra of doxorubicin

\begin{tabular}{cll}
\hline doxorubicin & \multicolumn{1}{c}{ Assignment } & \multicolumn{1}{c}{ Ref. } \\
\hline $454 \mathrm{~m}$ & $(\delta \mathrm{C}=\mathrm{O})$ & 27.28 \\
$985 \mathrm{w}$ & $(v \mathrm{C}-\mathrm{C})$ of ring A & 27.28 \\
$1212 \mathrm{w}$ & $(\delta \mathrm{O}-\mathrm{H})$ & 27.28 \\
$1275 \mathrm{~s}$ & $(v \mathrm{C}-0)$ of ring A & 27.28 \\
$1410 \mathrm{~s}$ & ring stretching & 27.28 \\
$1516 \mathrm{w}$ & $(v \mathrm{C}=\mathrm{C})$ of ring A & 27.28 \\
$1574 \mathrm{~m}$ & ring stretching & 27.28 \\
\hline
\end{tabular}

(abbreviations: s, strong: m, medium; w, weak; $\delta$ in planc bending: $v$. stretching)

doxorubicin, the bands of $\mathrm{sp}^{3}(v \mathrm{C}-\mathrm{H})$ and $\mathrm{sp}^{2}(v \mathrm{C}-\mathrm{H})$ are found [Figure (7a)]. In the case of calf thymus DNA and doxorubicin-DNA complex, however, those are not found $[$ Figure $(7 \mathrm{~b}),(7 \mathrm{c})]$. From the results of Figure 6 and Figure 7. we can be thought the intercalation model between doxorubicin and calf thymus DNA.

Therefore, we concluded that the loss of intensity of these bands confirmed the intercalation of $A, B$ and $C$ rings of doxorubicin in the double helix, thus preventing any contact with the silver mirror surfaces. Referring to the previous UVRRS and SГRS studies on doxorubicin-DNA complex, we suggested the plausible structure of doxorubicin-DNA complex as shown in Figure 8.

\section{Conclusions}

The antitumour agent, doxorubicin, does not have an appreciable absorbance in the UV range. Therefore, the UV-

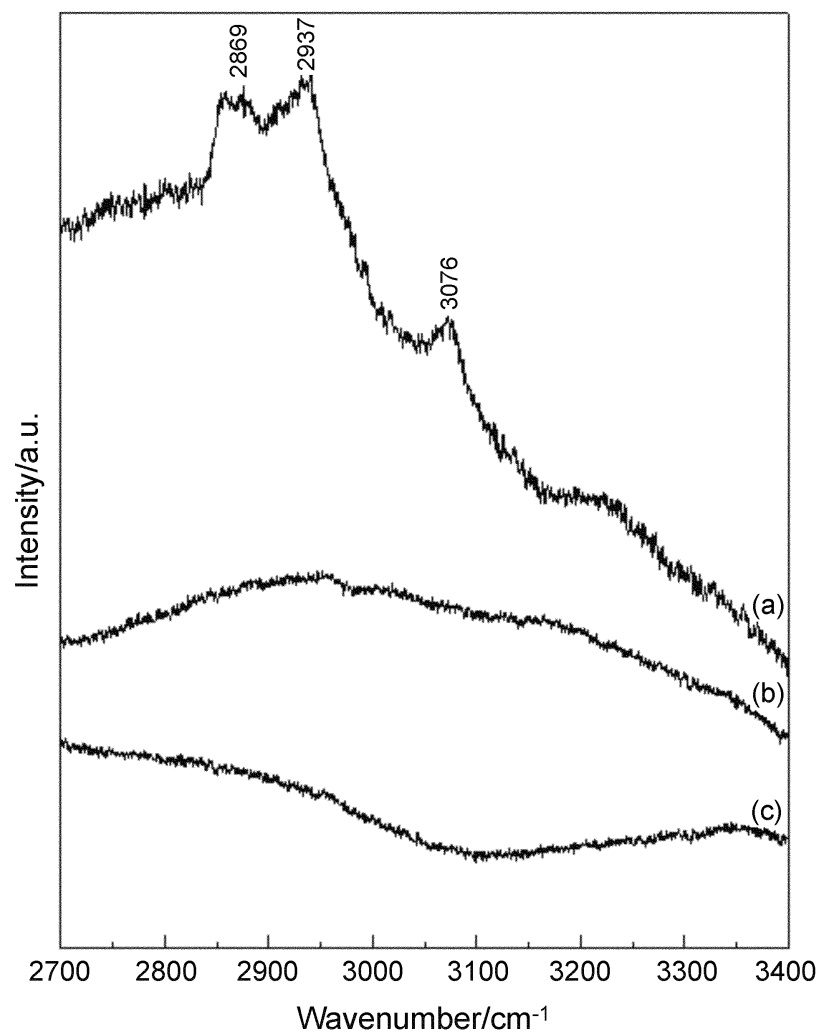

Figure 7. SLRS spectra of (a) $1.0 \times 10^{-6} \mathrm{M}$ of doxorubicin. (b) 1.1 $\times 10^{-5} \mathrm{M}$ of calf thymus D.NA and (c) $1.0 \times 10^{-\mathrm{i}} \mathrm{M}$ of doxorubicin $1.0 \times 10^{-5} \mathrm{M}$ or $\mathrm{D}$ NA complex. (molar ratio $1: 10$ )

resonance Raman spectroscopy with a $257 \mathrm{~nm}$ excitation wavelength was used to determine the doxorubicin-DNA binding site. A Surface Fnhanced Raman Scattering (SERS)

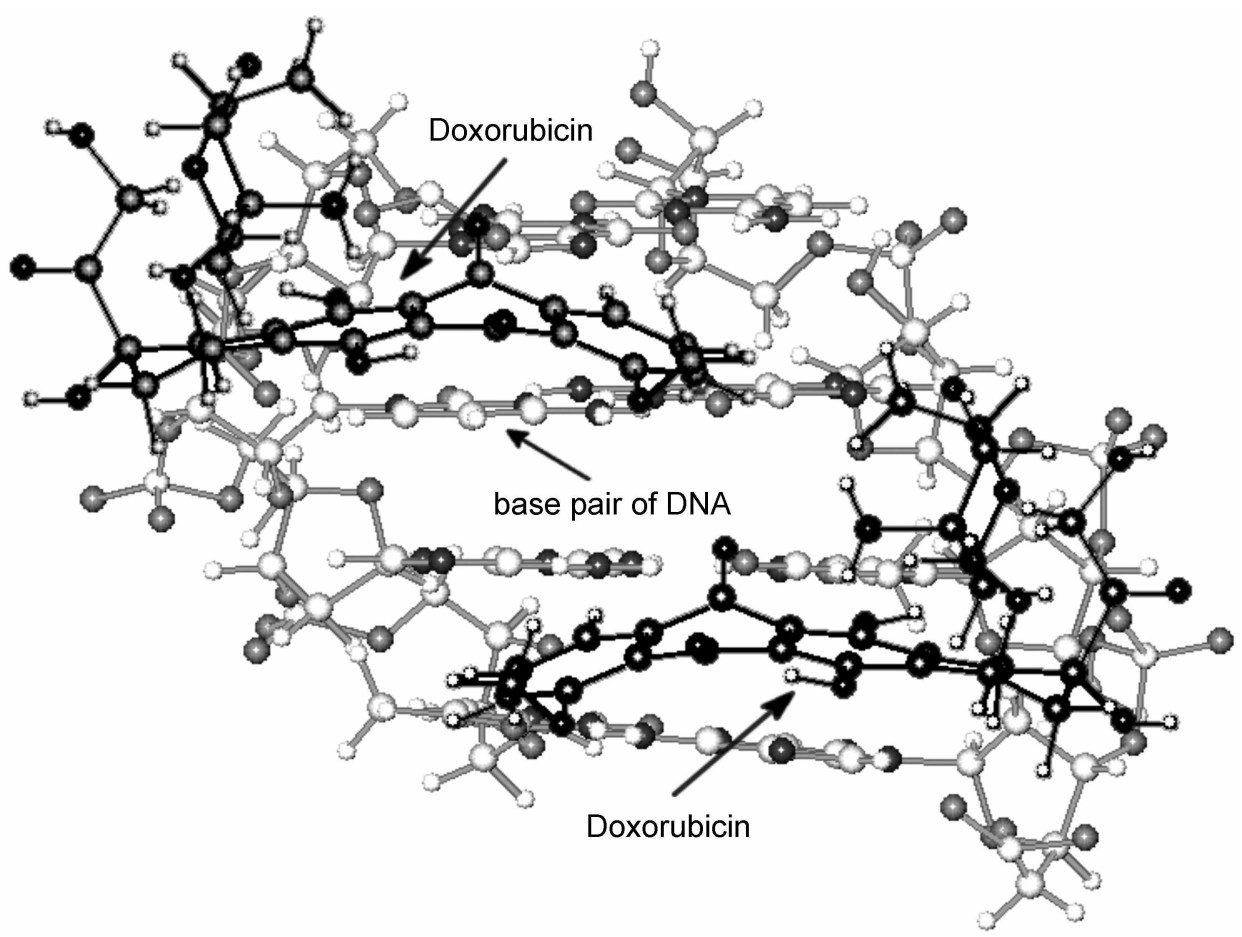

Figure 8. The plausible orientation of doxorubicin-DNA complex. 
spectroscopy was used to determine the interaction site of doxorubicin for doxorubicin-DNA complex. The observed spectral changes, as a result of the complex formation. lead us to the following conclusions: the interaction of doxorubicin with calf thymus DNA in an aqueous solution was realized by the drug binding to adenine and guanine. Doxorubicin interacted with the N7 position of adenine and guanine via a hydrogen bond formation between the N7 position of purine bases and the hydroxyl group of doxorubicin.

Acknowledgement. This work was supported by Korea Research Foundation Grant (KRF-2002-005-c00012).

\section{References}

1. Litu. L. F. Amm. Rev Biochem. 1989. 58.351.

2. Son. G. S.: Yeo. J. A.: Kim. M. S.: Kim. S. K.: Holmen. A.: Akernan. B: Nord ein. B. J. Am. Chent. Soc. 1998 . 20.6451.

3. Beljebbar, A.; Sockalingum, G. D.: Angiboust. I. F.: Manfait, M. Spectrochimt Acta Part t $1995,51,2083$.

4. Pigram. W. J.: Fuller. W.: Hamilton. L. D. Nature 1972. 235. 17.

5. Aubel-Sadron. G.: Londox-Gagliardi. D. Biochimie 1984. 66. 333.

6. Wang. A. H. J.: Ughetto. G.: Quigley. G. J.: Rich. A. Biochem. $1987,26,1152$

7. Manfait. M.: Bemard. L.: Theophanides, T. J. Raman Spectrosc. 1981, 11,68

8. Fodor. S. P. A.: Rava. R. P.: Hays. T. G.: Spiro. T. G. J.Am Chem. Soc. 1985.107. 1520 .

9. Fujimoto. N.: Toyama. A.: Takeuchi. H. J. Mol. Stuct. 1998, H77. 61.

10. Ziegler. L. D.: Hudson. B.: Strommen. D. P.: Peticolas, W. L. Biopolvmers 1984. 23. 2067.

11. Nabiev. I.: Chourpa. I.: Manfait. M. J. Phns. Ghem. 1994. 98. 1344

12. Min. E. S.: Nam. S. I.: Lee. M. S. Buh. Chem. Soc. Jpn. 2002. 75. 677.
13. Nam. S. I.: Min. E. S.: Tung. Y. M.: Lee. M. S. Bull. Korean Chem. Soc. 2001. 22.989.

14. Kim. M. S.; Kang, J. S.; Park, S. B.; Lee. M. S. Bull. Korean Chent Soc. 2003, 24. 633 .

15. Kang. J. S.; Lee, C. J; Kim, M. S.: Lee, M. S. Bull Korew Chent Soc. 2003. 24. 1599.

16. Moody. R. L.: Vo-Dinh. T.: Fletcher. W. H. Appl Speconsc 1987. H. 966.

17. Hou. X.: Wu, L: Xu, W.: Qin. L.: Wang, C.; Zhang, X: Shen, J. $J$ Colloids and surfaces A: Phosicochem. Eng Aspects $2002,198$. 135.

18. Jung. Y. M:: Lim1. T. W: Kimn. E. R.: Lee. H.: Lee. M. S. Bull. Kowan Chem. Soc. 2001. 22.318.

19. Kang. T. S.: Hwang. S. Y.: Lee. C. T.: Lee. M. S. Bull. Konean Chent Soc. 2002, 23. 1604

20. Saito. Y.: Wang. J. J.: Smith, D. A.; Batchelder. D. N. Lamgmin 2002. 18,2959

21. Tan. C.: Tasaka. H.: Yu. K. P.: Murphy. M.: Kanofshy. D. A Cancer 1967. 20. 333.

22. Brown. T. R. Prog Med Chem 1978. 15. 125.

23. Stanicŏva. J.: Fabriciova. G.; Chinsky. L.: Şutiak, V.: Miškovský. P. J. Mol. Smat. $1999.478,129$.

24. Wingrove, A. S.: Caret, R. L. Onganic Chemistr: Harper \& Row: Publishers: London. 1981.

25. Rajani. C.: Kincaid. J. R.: Petering. D. H. Biophus. Chem. 2001. 94. 219.

26. Benevides, J. M.: Thomas, P. Jr. Nucl Acid Res $1983,105,993$.

27. Prescott, B.: Steinmetz. G. J.: Thomas, P. Jr. Biopolntwers 1984. 23. 235 .

28. Miskowsky. P: Chinsky. L.: Wheeler. G. V.: Turpin. P. Y. $J$. Bionol Stuct Dnn. 1995.13.547.

29. Kocisová. E.: Chinsky. L.: Miskovshy. P. J. Biomol. Struct. Dyn. 1998. 15,1147 .

30. Strekal, N.: German, A:; Gachko, G.: Maskevich. A.: Maskevich. S. J. Mol. Stntct. 2001.563 .183$.

31. Smulevich. G.: Feiss. A. J. Phys. Chem 1986. 90.6388.

32. Moskovits. M.: Sulh. J. S. J. Plys. Chem. 1988. 92. 6327.

33. Moskorits. M. J. Phys. Chem 1982. 77.6327.

34. Nonaka. Y; Tsuboi. M.: Nakamoto, K. J. Raman Spectrosc. 1990. 21.133 . 